$$
\begin{gathered}
\text { 다공성 소재 종류에 따른 예혼합 평판버너의 } \\
\text { 연소 및 열효율 특성에 관한 연구 } \\
\text { 금성민 · 유병훈 }{ }^{*} \text {. 이창언 } \text {. 이승로 } \\
\text { 한라대학교 기계자동차공학부, "인하대학교 기계공학과 }
\end{gathered}
$$

(2012년 9월 20일 접수, 2012년 12월 1일 수정, 2012년 12월 1일 채택)

\title{
Characteristics of Combustion and Thermal Efficiency for Premixed Flat Plate Bumer Using a Porous Media
}

\author{
Sungmin Kum, Byeonghun $\mathrm{Yu}^{*}$, Chang-Eon Lee ${ }^{*}$ and Seungro Lee ${ }^{* \dagger}$ \\ School of Mechanical and Automotive Engineering, Halla University \\ ${ }^{*}$ School of Mechanical Engineering, Inha University
}

(Received 20 September 2012, Revised 1 December 2012, Accepted 1 December 2012)

요 약

본 연구는 현재 콘덴싱 보일러에 많이 사용하는 다공성 소재중에서 메탈화이버(metal fiber, MF) 및 세라믹 (ceramic, $\mathrm{CM}$ )으로 제작한 평판형 버너에 대해 연소 및 열톡성을 비교 검토하고 그 결과를 향후 개발할 EGR(Exhaust gas recirculation) 콘덴싱 보일러에 적용할 버너 선정의 기초자료로 활용하는 것을 목적으로 한다. $\mathrm{CO}$ 배출량은 $\mathrm{CM}$ 이 $\mathrm{MF}$ 보다 높았고 $\mathrm{NOx}$ 배출량은 $\mathrm{MF}$ 가 $\mathrm{CM}$ 보다 높게 나타났다. 버너열량 변화시에는 버너열량이 클수록 효율이 높게 나타났으며 버너 소재별 열효율은 버너열량 변화와 관계없이 MF가 CM보다 높게 나타났다. 본 실험범위에서 KS B 기준과 EN 677기준을 근거로 비례제어, 열효율, $\mathrm{CO}$ 및 NOx 배출량을 고려할 때 버너 소재는 MF가 적절하며 당량비는 0.8 일때가 최적 운전조건으로 판단된다.

주요어 : 콘덴싱보일러, 메탈화이버, 세라믹, 배기가스 재순환, 기공도

\begin{abstract}
The purpose of this study is investigated on the combustion and the thermal characteristics of porous media burners which are many using for a condensing boiler recently. In addition, results of this study will be used the fundamental information to decide the burner type which will be applied to the future development of EGR(Exhaust gas recirculation) condensing boiler. Two flat type of burners made of a the metal fiber(MF) and the ceramic $(\mathrm{CM})$ were selected and examined, experimentally. As experimental results, the emitted $\mathrm{CO}$ concentration of $\mathrm{CM}$ was higher than that of MF. However, the $\mathrm{NO}$ concentration of MF was higher than that of $\mathrm{CM}$ The efficiencies of both burners were increased as increasing the burner capacity. While the efficiency of $\mathrm{MF}$ was higher than that of $\mathrm{CM}$, regardless of the burner capacity. In the experimental range, $\mathrm{MF}$ is appropriated for the burner material and 0.8 of equivalence ratio is an optimal operation condition, regarding of the proportional control, the thermal efficiency and emitted $\mathrm{NO}$ and $\mathrm{CO}$ concentration based on the regulations of KS B standard and EN 677 standard.
\end{abstract}

Key words : Condensing boiler, Metal fiber, Ceramic, Exhaust gas recirculation, Porosity

\section{1. 서 론}

\footnotetext{
${ }^{\dagger}$ To whom corresponding should be addressed. School of Mechanical Engineering, Inha University E-mail : seungrol@inha.ac.kr
}

현재 사용되고 있는 보일러용 버너는 대부분 확산 화염의 분젠연소형태인데 분젠연소는 연소범위가 넓 어 운전영역의 과잉공기비 사용범위가 넓고 역화가 발생할 위험이 작다는 장점이 있다. 그러나 공기와 연료의 혼합톡성이 좋지 않아 전반적으로 화염의 길 
이가 길고 고온의 배기가스 배출로 인한 공해물질 $(\mathrm{CO}, \mathrm{NOx})$ 의 배출량이 많으며 효율을 향상시키는 데에도 한계가 있다 ${ }^{(1)}$ 또한 균일한 온도분포를 얻기 위하여 버너로부터 열교환기까지 충분한 거리를 확보 해야 하므로 보일러 전체 시스템의 크기가 커지게 되 고 부력의 영향으로 버너를 하향식이나 측향식으로 설치하는데 문제점이 있다란.

따라서 위와 같은 문제점을 해결하기 위해 콘덴싱 보일러가 개발되어 상용화되고 있는데 콘덴싱 보일 러의 연소방식은 예혼합방식으로 공기와 연료의 혼합 톡성이 좋아 $\mathrm{CO}$ 발생이 적고 화염온도가 분젠연소방 식에 비해 낮고 균일하여 NOx 발생이 적은 톡징이 있다. 또한 화염길이가 작아 연소실을 작게 구성할 수 있어 컴팩트한 연소시스템을 만들 수가 있다.

톡히 콘덴싱 보일러는 배기가스가 가지고 있는 현 열과 잠열을 동시에 회수할 수 있어 분젠연소방식의 보일러에 비해 효율을 향상시킬 수 있는 장점이 있다. 콘덴싱 보일러의 핵심기술은 버너, 열교환기, 송풍기 및 제어기술 등이 있는데 버너와 열교환기는 환경오 염물질과 효율 측면에서 매우 중요한 인자이다.

콘덴싱 보일러에서 많이 사용하는 평판형 버너의 소재는 화염안정성이 중요한 요소이기 때문에 다공성 소재인 메탈화이버(metal fiber), 세라믹(ceramic), 금 속다공판(perforate plate) 및 스테인레스 핀(stainless steel fin) 등이 사용되고 있다. ${ }^{(3-8)}$

일반적으로 다공성 소재를 사용한 버너들은 미연혼 합기의 예열효과로 인해 예열재열연소(regenerative combustion)와 완전연소가 가능하고, 효율적인 내부 재순환에 의해 가연한계를 확장할 수 있다. 이것은 내부에너지 재순환과 예열효과로 $\mathrm{CO}$ 및 UHC(Unburned hydrocarbon)를 감소시킬 수 있다. 또한 많은 양의 공기가 공급되어 상대적으로 낮은 온 도에서 화학반응이 일어나기 때문에 온도의 영향을 많이 받는 NOx를 효과적으로 줄일 수 있는 있는데 ${ }^{(9)}$ 다공성 재질의 종류별 톡징은 다음과 같다.

메탈화이버(MF)는 기공도(porosity)가 다른 다공성 소재보다 높아 $(80 \%$ 이상 $)$ 압력손실이 작다는 장점을 가지고 있다. 또한 자유롭게 형상변경이 가능하므로 평판형, 원통형 등 다양한 형태로 제작이 가능하고 적열시에도 내구성에는 큰 문제가 없는 것으로 알려 져 있다. ${ }^{(5)}$

세라믹 $(\mathrm{CM})$ 은 내구성 및 부식성이 좋고 표면형상 을 자유롭게 성형할 수 있어 보염구조 및 균일한 화
염을 보이는 장점이 있으나 저부하시 화염길이가 짧 아져 버너 표면이 적열될 경우 표면의 온도가 높아진 다. 또한 재료의 취성이 약하여 쉅게 깨지고 화염면 이 물에 취약하다는 단점이 있다.

금속 다공판이나 스테인레스 핀은 다양한 형태의 화염구 제작이 가능하며 적정한 화염면을 형성시킬 수 있는 장점이 있지만 저부하시 화염면이 적열될 경 우 금속표면이 열에 의하여 팽창 및 수축되는 과정에 서 변형이 생길 수 있는 단점이 있다.

이와 같이 버너의 소재에 따라 연소톡성이 중요하 기 때문에 많은 연구 ${ }^{(3-13)}$ 가 진행되었지만 주로 톡정 소재의 버너들에 대한 연소 및 열톡성을 규명한 것으 로 EGR(exhaust gas recirculation) 콘덴싱 보일러와 같은 새로운 보일러 시스템에 적용할 버너를 선정하 기 위해서는 버너 소재에 따른 톡성의 상대적 비교가 필요하다

본 연구는 현재 콘덴싱 보일러에 많이 사용하는 다 공성 소재중에서 메탈화이버(MF), 세라믹 $(\mathrm{CM})$ 을 소 재로 제작한 평판형 버너에 대해 연소 및 열톡성을 비교 검토한 후 그 결과를 향후 개발할 $\mathrm{EGR}$ 콘덴싱 보일러에 적용할 버너 선정의 기초자료로 활용하는 것을 목적으로 한다. 따라서 소재별 연소특성에 대한 실험을 수행한 후 최종적으로 열교환기와 결합하여 각각의 연소 및 열효율 톡성을 비교 분석하였다.

\section{2. 버너 및 실험방법}

\section{2-1. 평판형 예혼합 버너}

그림 1은 본 연구에서 사용한 예혼합 다공성 평판 버너를 나타낸 것으로 소재는 메탈화이버(MF)와 세 라믹 $(\mathrm{CM})$ 을 사용하였다.

$\mathrm{MF}$ 는 $50 \mu \mathrm{m}$ 이하의 이트륨 원소로 접합시킨 철크롬 합금제의 금속섬유직조의 면으로 짠 다공체판으 로 높은 유연성과 다양한 형태로의 제작이 용이하여

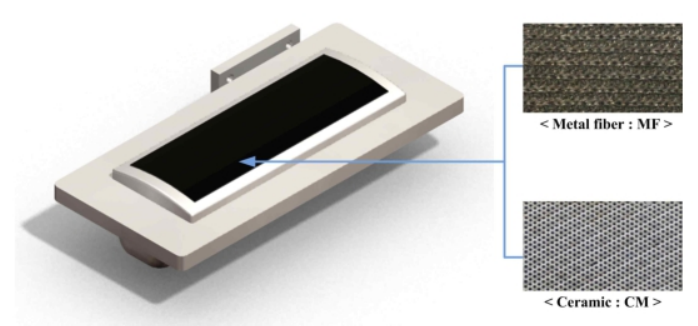

Fig. 1. Detail diagram of burner and porous media 
현재 콘덴싱 보일러 연소기 표면 재질로 가장 많이 사용되고 있다. 기공도(porosity)는 약 $89 \%$ 이다.

$\mathrm{CM}$ 은 기공의 지름이 약 $1.35 \mathrm{~mm}$, 기공도가 약 $49.5 \%$ 이며 재질은 cordierite로서 내열성이 우수하고 고온에서도 화학반응에 대한 촉매역할을 하지 않으므 로 안정된 예혼합화염을 생성시키기가 용이하다.

버너의 전체크기는 $187 \mathrm{~mm} \times 73 \mathrm{~mm}$ (연소면의 크기 는 $175 \mathrm{~mm} \times 56.6 \mathrm{~mm}$ )로서 콘덴싱 보일러에서 사용하 는 버너 크기(보일러 용량 $23 \mathrm{~kW}$ 기준)와 동일하며 버너 버너열량은 비례제어에 적용하기 위해 15,20 , $25 \mathrm{~kW}$ 로 변화시키면서 실험을 수행하였다.

\section{2-2. 실험방법}

Fig. 2는 실험장치의 개략도로서 연료는 천연가스 (natural gas, NG)를 사용하였으며, 연소용 공기는 콤 프레서(screw type, $11.19 \mathrm{~kW}$ )를 이용한 압축공기를 사용하였다. 연료와 공기는 모두 정밀 레귤레이터를 통해 일정한 압력으로 질량유량계(MFC Tylan $\mathrm{FC}$ 280)에 공급된다. 질량유량계를 통해 제어된 연료와 공기는 믹서에서 균일하게 혼합된 후 버너에 공급되 도록 구성되어 있다.

버너 아랫부분에는 열교환기가 있는데 열교환기 는 현재 콘덴싱 보일러에 사용하는 모델로서 부식 및 내구성 강화를 위해 케이스의 재질은 스테인리스이고 사각형 구조로 되어있다. 열교환기는 상부 및 하부 열교환기로 구성되어 있으며 상부 열교환기는 핀튜브 형태의 현열 열교환기이며, 하부는 잠열 회수를 위한 판형 형태이다.

연소시 최종 배출되는 배기가스의 농도 측정은 연 소가스 분석기(testo 340)를 사용하였다. 배기가스 및 열교환기의 물온도는 열전대(K type)를 이용하여 데 이터로거(HP 34970A)에 연결하여 측정하였다. 열교 환기 입출구의 물 유량은 디지털유량계 (RT375MI-LPM1)를 사용하여 제어하였고, 배기가스 농도는 열교환기 윗부분에 설치한 배기관 출구부에서 측정하였다. 모든 실험의 데이터는 정상 상태에서 10 회 측정한 평균값을 사용하였다.

식 (1)은 시스템의 열효율을 계산하기 위한 식으로

$$
\begin{aligned}
& \eta=\frac{m_{w} \times C_{p w} \times\left(T_{o}-T_{i}\right)}{Q_{\text {fuel }}} \\
& Q_{f \text { uel }}=m_{g} \times \text { heat value of } N G
\end{aligned}
$$

여기서 $m_{w}$ 는 물 유량, $C_{p w}$ 는 배기가스의 정압비

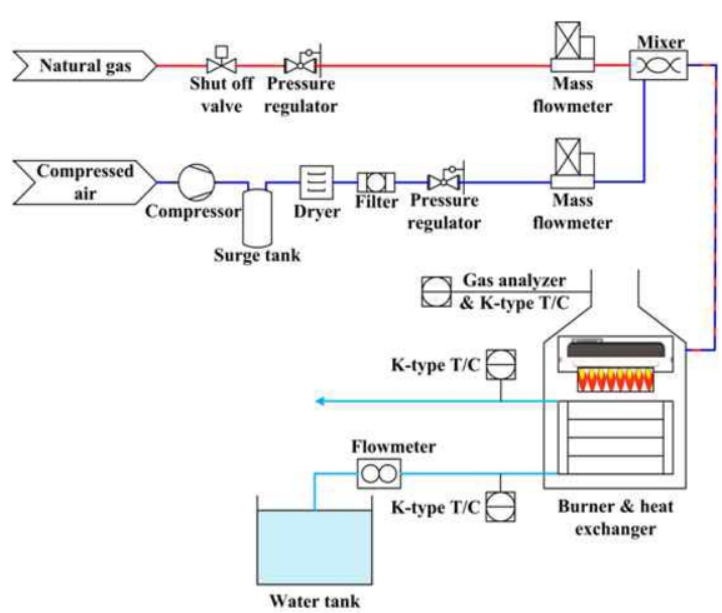

Fig. 2. Schematic diagram of experimental apparatu

\begin{tabular}{|c|c|c|}
\hline 버너 종류 & Metal fiber(MF) & Ceramic (CM) \\
\hline 버너크기(mm) & \multicolumn{2}{|c|}{$175 \times 56.6$} \\
\hline 당량비 & \multicolumn{2}{|c|}{$0.8,0.85,0.9,0.95$} \\
\hline 버너열량(kW) & \multicolumn{2}{|c|}{$15,20,25$} \\
\hline
\end{tabular}

Table. 1. Experimental condition

Table. 2. Detailed value of flow rates for fuel, air and

\begin{tabular}{|c|c|c|c|c|}
\hline $\begin{array}{c}\text { Burner } \\
\text { Cap. } \\
(\mathrm{kW}) \\
\end{array}$ & $\begin{array}{l}\text { Equivalen } \\
\text { ce ratio }\end{array}$ & $\begin{array}{c}\text { Fuel } \\
(\mathrm{L} / \mathrm{min})\end{array}$ & $\begin{array}{c}\text { Air } \\
(\mathrm{L} / \mathrm{min})\end{array}$ & $\begin{array}{c}\text { Water } \\
(\mathrm{kg} / \mathrm{min})\end{array}$ \\
\hline \multirow{4}{*}{15} & 0.80 & \multirow{4}{*}{20.7} & 271.3 & \multirow{12}{*}{11.98} \\
\hline & 0.85 & & 255.3 & \\
\hline & 0.90 & & 241.1 & \\
\hline & 0.95 & & 228.5 & \\
\hline \multirow{4}{*}{20} & 0.80 & \multirow{4}{*}{27.6} & 361.7 & \\
\hline & 0.85 & & 340.4 & \\
\hline & 0.90 & & 321.5 & \\
\hline & 0.95 & & 304.6 & \\
\hline \multirow{4}{*}{25} & 0.80 & \multirow{4}{*}{34.4} & 452.1 & \\
\hline & 0.85 & & 425.5 & \\
\hline & 0.90 & & 401.9 & \\
\hline & 0.95 & & 380.8 & \\
\hline
\end{tabular}
water

Table. 3. Uncertainty analysis of efficiency

\begin{tabular}{c|c|c|c|c}
\hline$X_{i}$ & Unit & Value & $\delta X_{i}$ & $\left(\frac{\delta X_{i}}{\eta} \frac{\partial \eta}{\partial X_{i}}\right) \times 100(\%)$ \\
\hline \hline$T_{w, i}$ & ${ }^{\circ} \mathrm{C}$ & 23.2 & 0.12 & 0.47 \\
\hline$T_{w, o}$ & ${ }^{\circ} \mathrm{C}$ & 48.9 & 0.32 & 1.25 \\
\hline$m_{w}$ & $\mathrm{~kg} / \mathrm{min}$ & 11.98 & 0.62 & 5.17 \\
\hline$m_{g}$ & $\mathrm{~L} / \mathrm{min}$ & 34.4 & 0.05 & 0.15 \\
\hline \multicolumn{5}{c}{ Total $\eta$ Uncertainty : $\delta \eta / \eta=5.84$} \\
\hline
\end{tabular}




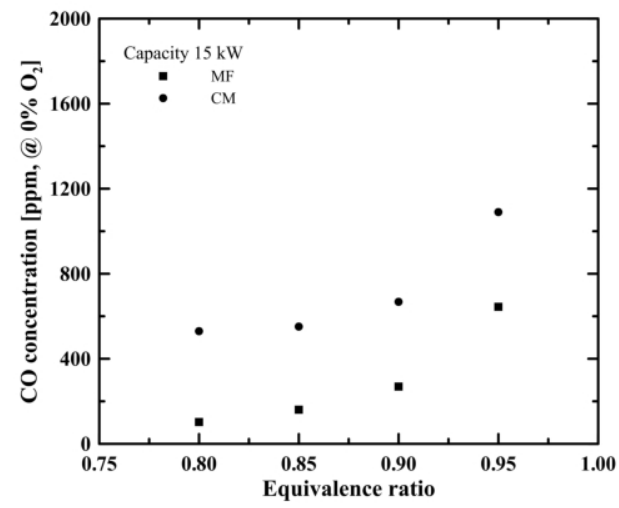

Fig. 3. $\mathrm{CO}$ concentration of $\mathrm{MF}$ and $\mathrm{CM}$ burner with equivalence ratio(Capacity $15 \mathrm{~kW}$ )

열, $T_{o}$ 는 열교환기 출구 물온도, $T_{i}$ 는 열교환기 입구 물온도이다

실험조건은 Table. 1 과 같으며, 당량비는 실용연소 기의 운전범위를 고려하여 $0.80 \sim 0.95$ 까지 0.05 씩 변 화시켰고 당량비 변화에 따른 연료량, 공기량 및 열 교환 물 유량은 Table. 2 와 같다. 실험에서 사용한 질 량유량계, 연소가스 분석기, 디지털유량계 및 데이터 로거의 정밀도는 각각 $\pm 1 \%, \pm 5 \%, \pm 2 \%, \pm 1 \%$ 이다.

실험결과에 대한 불확실도 해석(uncertainty analysis)을 위하여 $\mathrm{Kline}^{(14)}$ 의 방법을 사용하였다. 계 산한 결과 Table 3에 의하면 MF 버너에서 버너열량 $25 \mathrm{~kW}$, 당량비 0.8 일 때 열효율의 불확실도는 $5.84 \%$ 이다. 이때 열교환기 물 유량 $\left(m_{w}\right)$ 의 불확실도가 가 장 크게 나타나고 NG 유량의 불확실도가 가장 낮게 나타났다.

\section{3. 결과 및 고찰}

3-1. 버너열량 변화에 따른 $\mathrm{CO}$ 및 $\mathrm{NOx}$ 배출특성

Fig. 3은 $\mathrm{MF}$ 와 $\mathrm{CM}$ 버너를 각각 열교환기에 장착 하고 버너열량 $15 \mathrm{~kW}$ 일 때 당량비 변화에 따른 $\mathrm{CO}$ 배출톡성을 나타낸 것으로 버너 종류에 관계없이 당 량비가 증가할수록 $\mathrm{CO}$ 는 전체적으로 증가한다. 이것 은 당량비가 증가할수록 $\mathrm{CO}$ 를 산화시킬 수 있는 $\mathrm{O}_{2}$ 의 유효성이 감소하고 ${ }^{(15)}$ 또한 연소실내에서 연소가 스의 체류시간 변화 때문으로 생각된다.

버너 소재별 $\mathrm{CO}$ 배출량은 $\mathrm{CM}$ 이 $\mathrm{MF}$ 보다 높게 나타나는데 이것은 $\mathrm{MF}$ 의 경우 기공도가 $\mathrm{CM}$ 보다 크 기 때문에(기공도 $\mathrm{MF}>\mathrm{CM}$ ) 예혼합기의 분출속도가 작고 따라서 화염길이가 작아지기 때문에 나타나는 현상(Fig. 10 참조)이라고 판단되며 최저 발생량은

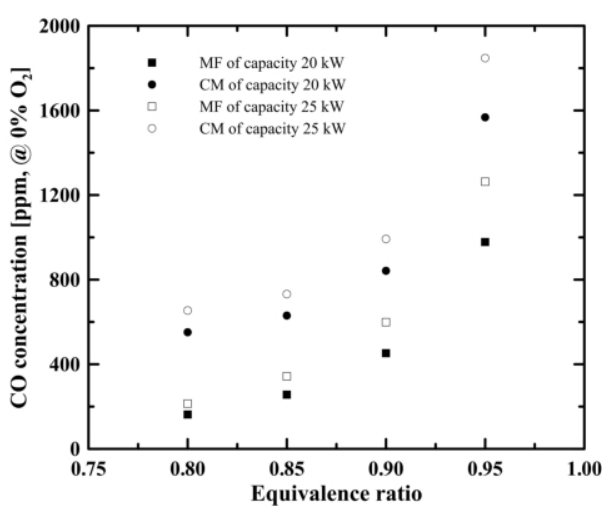

Fig. 4. $\mathrm{CO}$ concentration of $\mathrm{MF}$ and $\mathrm{CM}$ burner with equivalence ratio(Capacity 20,25kW)

$\mathrm{MF}$ 가 당량비 0.8 일 때 약 $103 \mathrm{ppm}$ 이며 최고 발생량 은 $\mathrm{CM}$ 이 당량비 0.95 일 때 약 $1,090 \mathrm{ppm}$ 이다.

Fig. 4는 버너열량이 $20,25 \mathrm{~kW}$ 일 때 당량비 변화 에 따른 $\mathrm{CO}$ 배출톡성을 나타낸 것으로 전체적인 경 향은 Fig. 3 과 유사하나 $\mathrm{CO}$ 절대량은 버너열량이 커 질수록 높게 나타난다. 버너열량에 따른 $\mathrm{CO}$ 값을 비 교하면 $\mathrm{MF}$ 버너에서 당량비 0.8 일 때 $15 \mathrm{~kW}$ (Fig. 3 참조)에서는 $103 \mathrm{ppm}, 20 \mathrm{~kW}$ 에서는 $162 \mathrm{ppm}, 25 \mathrm{~kW}$ 에서는 $214 \mathrm{ppm}$ 으로 버너열량이 커질수록 $\mathrm{CO}$ 량은 큰 폭으로 증가한다. 이것은 버너열량이 커질수록 혼 합기량이 증가하면서 유속이 증가하고 화염길이가 상 대적으로 길어지기 때문으로 생각된다.

가정용 보일러의 경우 $\mathrm{CO}$ 발생 요인은 불완전 연 소보다는 주로 열교환기에 의한 quenching 현상 ${ }^{(15)}$ 과 버너열량 변화에 따라 연소가스의 연소실내 체류시간 이 원인이다. 즉 당량비가 증가할수록 화염길이가 길 어지기 때문에 quenching 효과가 있을 수 있으며, 버 너열량이 증가할수록 버너 표면의 유속이 상대적으로 증가하면서 연소가스가 연소실내 체류시간이 감소함 에 따라 $\mathrm{CO}$ 에서 $\mathrm{CO}_{2}$ 로의 산화시간이 적어 $\mathrm{CO}$ 발생 량이 많아질 수 있다. 또한 동일한 당량비 및 버너열 량에서는 버너의 기공도가 작을수록 화염길이가 길어 지기 때문에 $\mathrm{CO}$ 배출량은 높게 나타난다고 생각된 다.

결과적으로 버너열량이 커질수록 $\mathrm{CO}$ 량을 줄일려 면 버너와 열교환기의 거리를 증가시켜 연소가스의 연소실내 체류시간을 늘려주거나 버너의 기공도를 크 게 하여 화염길이를 줄여주어야 하는데 최근 가정용 보일러가 컴팩트화 되면서 연소실 체적(버너와 열교 환기 사이의 거리)을 증가시키는 것은 한계가 있으므 


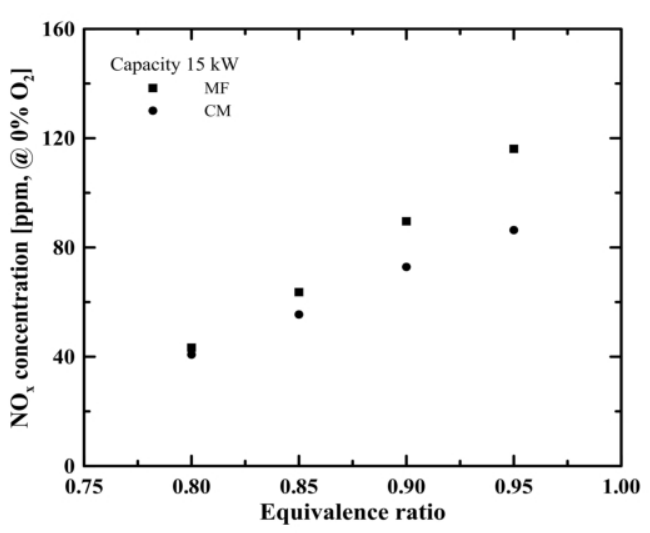

Fig. 5. NOx concentration of $\mathrm{MF}$ and $\mathrm{CM}$ burner with equivalence ratio(Capacity $15 \mathrm{~kW}$ )

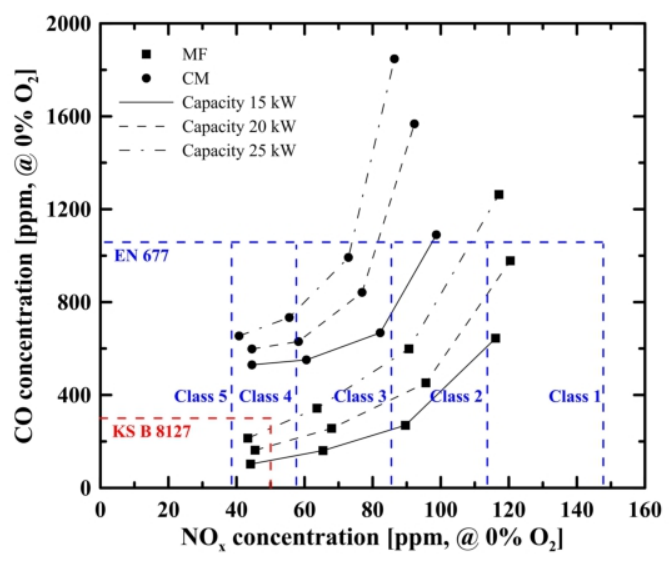

Fig. 7. $\mathrm{CO}$ and $\mathrm{NOx}$ concentration for $\mathrm{MF}$ and $\mathrm{CM}$ burner

로 버너 기공도에 대한 고찰이 필요할 것으로 판단된 다.

Fig. 5는 버너열량이 $15 \mathrm{~kW}$ 일 때 당량비 변화에 따 른 NOx 배출톡성을 나타낸 것으로 버너 종류에 관계 없이 당량비가 증가할수록 $\mathrm{NOx}$ 는 전체적으로 증가 한다.

일반적으로 천연가스의 경우 질소함유율이 매우 낮기 때문에 연소시 배출되는 NOx는 대부분 thermal $\mathrm{NOx}$ 이며 따라서 $\mathrm{NOx}$ 량은 화염온도에 따라 좌우되 기 때문에 당량비가 증가할수록 화염온도가 상승하여 $\mathrm{NOx}$ 배출량이 높게 ${ }^{(15)}$ 나타난다.

버너 소재별 $\mathrm{NOx}$ 배출량은 $\mathrm{CM}$ 보다는 $\mathrm{MF}$ 가 높게 나타내고 있는데 Fig. 3, 4의 $\mathrm{CO}$ 배출톡성과는 반대 현상이다. 이것은 버너의 기공도에 따른 차이로서 기 공도가 작을수록 유속이 빨라지고 따라서 연소가스 속도가 증가함에 따라 연소실내에서 고온으로 체류하 는 시간이 짧아지기 때문에 일어나는 현상으로 판단

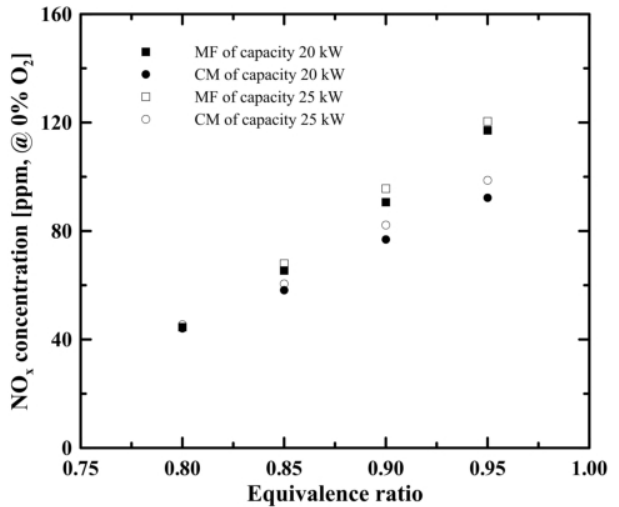

Fig. 6. NOx concentration of $\mathrm{MF}$ and $\mathrm{CM}$ burner with equivalence ratio(Capacity $20,25 \mathrm{~kW}$ )

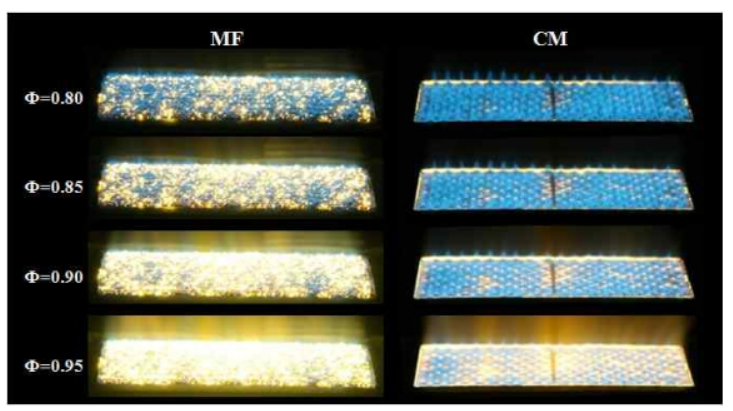

Fig. 8. Flame images of $M F$ and $C M$ burner at various equivalence ratios

된다. $\mathrm{NOx}$ 최대 배출량은 당량비가 0.95 일 때 $\mathrm{MF}$ 가 약 $116 \mathrm{ppm}, \mathrm{CM}$ 이 약 $86 \mathrm{ppm}$ 이다.

Fig. 6은 버너열량이 $20,25 \mathrm{~kW}$ 일 때 당량비 변화 에 따른 $\mathrm{NOx}$ 배출톡성을 나타낸 것으로 전체적인 경 향이 Fig. 5와 유사하며 특히 버너 소재와 당량비가 동일할 경우 버너열량이 변해도 $\mathrm{NOx}$ 배출량 차이는 매우 작다는 것을 알 수 있다. 즉 연소실 체적이 작은 가정용 보일러의 경우 버너 종류 변화에 따른 $\mathrm{NOx}$ 발생 메카니즘은 $\mathrm{CO}$ 발생 메카니즘에 비해 그 영향 이 상대적으로 작다고 생각된다.

Fig. 7은 $\mathrm{MF}$ 와 $\mathrm{CM}$ 버너의 $\mathrm{CO}$ 와 $\mathrm{NOx}$ 배출량간 의 상관관계를 나타낸 것이다. 확산화염형 버너에서 는 당량비 1 이하일 때 $\mathrm{NOx}$ 량이 증가하면서 $\mathrm{CO}$ 량도 증가하지만 당량비 1 이상에서는 $\mathrm{NOx}$ 량은 감소하지 만 $\mathrm{CO}$ 배출량이 증가하는 $\mathrm{NOx}-\mathrm{CO}$ trade-off 관계 ${ }^{(15)}$ 가 나타나는 것이 일반적이다. 본 연구에서 사용한 예혼합 버너의 경우에도 본 실험범위 내(당량비 1 이 
하)에서는 버너열량과 당량비가 변해도 NOx 배출량 이 증가하면 $\mathrm{CO}$ 배출량도 증가한다.

한국에서 콘덴싱 보일러 $\mathrm{CO}$ 배출량은 $300 \mathrm{ppm}$ 이 하, $\mathrm{NOx}$ 배출량은 $50 \mathrm{ppm}$ 이하 ${ }^{(16)}$ 로 기준을 정하고

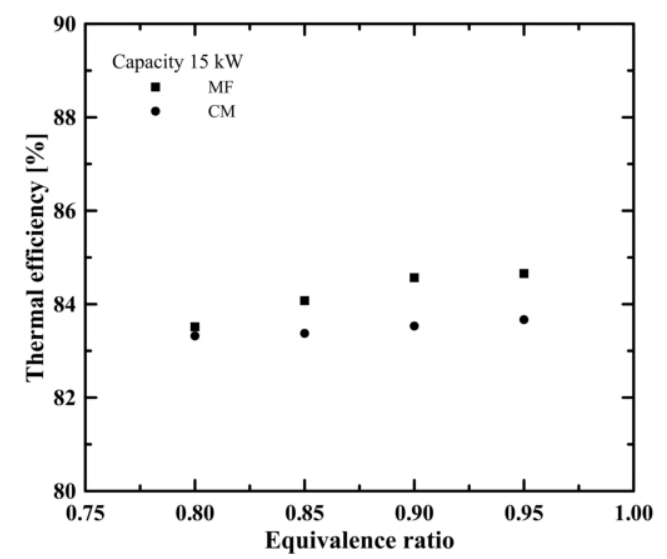

Fig. 9. Thermal efficiency of $\mathrm{MF}$ and $\mathrm{CM}$ burner system with equivalence ratio(Capacity $15 \mathrm{~kW}$ )

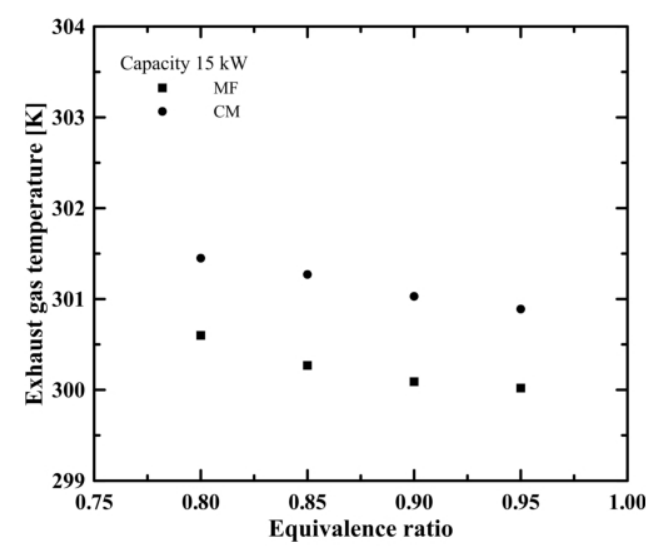

Fig. 10. Exhaust gas of $\mathrm{MF}$ and $\mathrm{CM}$ burner system with equivalence ratio(Capacity $15 \mathrm{~kW}$ )

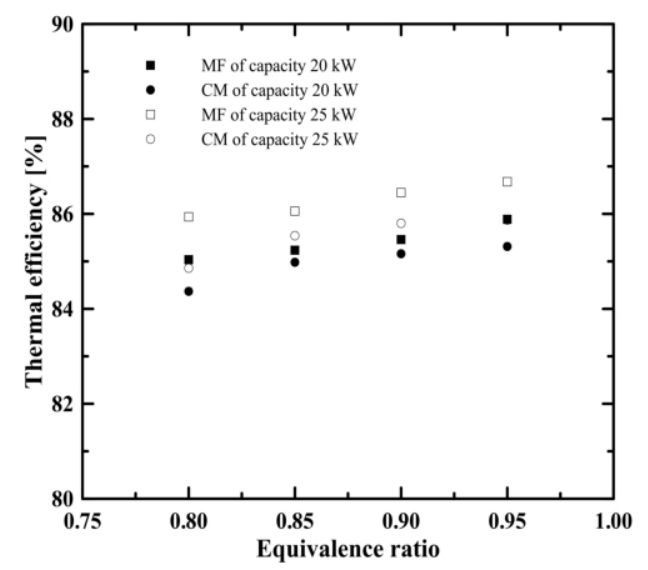

Fig. 11. Thermal efficiency of $M F$ and $C M$ burner system with equivalence ratio(Capacity $20,25 \mathrm{~kW}$ )
있고(KS B 8127), EN Product Standards ${ }^{(17)}$ 에서는 $\mathrm{CO}$ 배출량은 $1,070 \mathrm{ppm}$ 이하, NOx는 39.7 147.4ppm이하로 규정(EN 677)하고 있으며 $\mathrm{NOx}$ 배출량에 따라 5 단계로 구분하고 있다.

이 규정을 기준으로 본 연구에서 사용한 $\mathrm{MF}$ 와 $\mathrm{CM}$ 버너에서 버너열량 변화에 따른 $\mathrm{CO}$ 및 $\mathrm{NOx}$ 배 출톡성을 검토한 결과 $\mathrm{MF}$ 버너는 당량비가 0.8 일 때 버너열량에 관계없이 $\mathrm{KS}$ 기준을 만족하고 있으며 EN 677에서는 Class 4(NOx 범위 : 35.7 56.7ppm 이하) 범위에 속하는 것으로 나타났기 때문에 위에서 언급한 조건이 최적 운전조건으로 판단된다.

Fig. 8 은 버너열량이 $15 \mathrm{~kW}$ 일 때 당량비 변화에 따 른 버너의 화염사진이다. $\mathrm{MF}$ 와 $\mathrm{CM}$ 버너 모두 당량 비 0.8 과 0.85 에서 비교적 안정적이며 당량비 0.95 에 서는 적화현상이 나타났다. 일반적으로 평면화염의 경우 당량비 변화에 따라 부착화염에서 부상화염으로 형태가 바뀌는데 당량비가 낮아짐에 따라 예혼합화염 의 톡성값인 화염전파속도가 감소하고 공기량이 증가 하면서 버너표면의 분사속도가 증가하여 화염이 점차 부상하는 ${ }^{(18)}$ 특징을 갖는다. 화염이 부상될 경우에는 quenching 이나 소음 등이 일어날 수 있고, 화염이 부착될 경우에는 화염면이 적열되어 내구성에 문제가 생길 수 있다.

\section{3-2. 버너열량 변화에 따른 시스템 열효율}

Fig. 9는 버너열량 $15 \mathrm{~kW}$ 일 때 당량비 변화에 따른 시스템 열효율을 나타낸 것으로 버너 소재에 관계없 이 당량비가 증가할수록 화염온도가 높아져 열효율은 상승한다.

버너별 열효율은 $\mathrm{CM}$ 이 $\mathrm{MF}$ 보다 낮게 나타나는데 이것은 버너의 기공도가 작아질수록 혼합기의 유량분 배에 대한 압력강하가 증가하여 화염이 불안정해져서 열교환기와 충분한 열교환이 이루어지지 않기 때문이 다. 특히 위에서 언급한 열효율은 열교환기 출구 배 기가스 온도(Fig. 10 참조)에서도 확인할 수 있는데 당량비가 증가할수록 배기가스 온도는 낮아지며 $\mathrm{MF}$ 가 $\mathrm{CM}$ 보다 더 낫게 나타났다.

Fig. 11은 버너열량 $20,25 \mathrm{~kW}$ 일 때 당량비 변화에 따른 시스템 열효율을 나타낸 것으로 전체적인 경향 은 Fig. 9와 유사하다. 버너열량 변화시에는 버너열량 이 클수록 효율이 높게 나타났으며 버너 소재별 열효 율은 버너열량 변화와 관계없이 $\mathrm{MF}$ 가 $\mathrm{CM}$ 보다 높게 나타났다. 본 실험범위내에서 시스템 최대 열효율은 
$\mathrm{MF}$, 버너열량 $25 \mathrm{~kW}$, 당량비 0.95 일 때 약 $86.7 \%$ 이 다.

지금까지 콘덴싱 보일러에 많이 사용하는 다공성 소재중에서 $\mathrm{MF}$ 와 $\mathrm{CM}$ 을 소재로 제작한 평판형 버너 에 대해 연소 및 열효율 톡성을 비교한 결과 버너 종 류별 $\mathrm{CO}$ 배출량은 버너열량 및 당량비에 관계없이 $\mathrm{CM}$ 이 $\mathrm{MF}$ 보다 높게 나타났고, $\mathrm{NOx}$ 배출량은 $\mathrm{MF}$ 가 $\mathrm{CM}$ 보다 높게 나타났으며 열효율은 $\mathrm{MF}$ 가 $\mathrm{CM}$ 보다 높게 나타났다.

결론적으로 향후 개발할 EGR 콘덴싱 보일러에 적 용할 버너에 대해 연소 및 열효율을 톡성을 고려하면 버너 소재는 $\mathrm{MF}$ 가 적절하며 비례제어, 열효율, $\mathrm{CO}$ 및 $\mathrm{NOx}$ 배출량을 고려할 때 당량비 0.8 일때가 최적 운전조건으로 판단된다.

\section{4. 결 론}

본 연구는 현재 콘덴싱 보일러에 많이 사용하는 다 공성 소재중에서 $\mathrm{MF}$ 와 $\mathrm{CM}$ 버너에 대해 연소 및 열 특성을 비교 검토하여 향후 개발할 EGR 콘덴싱 보 일러에 적용할 버너를 선정하기 위한 것으로 다음과 같은 결론을 얻었다.

1) 버너 소재별 $\mathrm{CO}$ 배출량은 $\mathrm{CM}$ 이 $\mathrm{MF}$ 보다 높은데 이것은 $\mathrm{MF}$ 의 경우 기공도가 $\mathrm{CM}$ 보다 크기 때문 에(기공도 $\mathrm{MF}>\mathrm{CM}$ ) 예혼합기의 분출속도가 작고 따라서 화염길이가 작아지기 때문으로 판단된다.

2) 버너 종류별 $\mathrm{NOx}$ 배출량은 $\mathrm{MF}$ 가 $\mathrm{CM}$ 보다 높게 나타내고 있는데 이것은 버너의 기공도에 따른 차이로서 기공도가 작을수록 유속이 빨라지고 따 라서 연소가스 속도가 증가함에 따라 연소실내에 서 고온으로 체류하는 시간이 짧아지기 때문에 일어나는 현상으로 판단된다.

3) 버너열량 변화시에는 버너열량이 클수록 효율이 높게 나타났으며 버너 소재별 열효율은 버너열량 변화와 관계없이 $\mathrm{MF}$ 가 $\mathrm{CM}$ 보다 높게 나타났다.

4) 본 실험범위에서 $\mathrm{KS} \mathrm{B}$ 기준과 $\mathrm{EN} 677$ 기준을 근 거로 비례제어, 열효율, $\mathrm{CO}$ 및 $\mathrm{NOx}$ 배출량을 고 려할 때 버너 소재는 $\mathrm{MF}$ 가 적절하며 당량비는 0.8 일때가 최적 운전조건으로 판단된다.

\section{참고문헌}

1. P. Muthukumar, P. I. Shyamkumar, Development of novel porous radiant burners for LPG cooking applications, Fuel;doi:10.1016/j.fuel.2011.09.006

2. Patrizia M, Andrea D, Mario C, Rocco P, Giuseppe T, Claudio A, Emission of Ultrafine Particles from Natural Gas Domestic Burners, Environmental Engineering Science, 2008, 25, pp. 1357-1363.

3. 이재영, 이필형, 박창수, 박봉일, 황상순, 2009 , 평판 예 혼합 세라믹 버너의 분포판 변화에 따른 연소화염특성과 안전성 분석, 2009, 한국연소학회지, Vol 14, No. 4, pp. 7-16.

4. 김영수, 조승완, 김규보, 장영준, 전충환, 다공성 세라믹 매트를 이용한 복사버너에서의 연소라디칼 톡성과 배기 배출물에 관한 연구, 2007, 대한기계학회논문집, pp. 539-546.

5. 정종수, 이교우, 세라믹 매트릭스 버너에 형성된 예혼합 화염의 NOx 및 CO 배출특성, 1996, 대한기계학회논문 집(B), pp. 3243-3250.

6. 박창권, 장덕표, 손승길, 박인석, 소결매트를 이용한 평판 형 예혼합 가스버너의 연소톡성, 2010, 제 40회 $\mathrm{KOSCO}$ SYMPOSIUM논문집, pp. 293-298

7. 정준영, 김영모, 메탈화이버 버너의 화염구조 및 공해불 질 배출 톡성, 2011, 한국연소학회지, Vol 16, No. 3, pp. 27-32.

8. S. Afsharvahid, P.J. Ashman, B.B. Dally, Investigation of NOx conversion characteristics in a porous medium, Combustion and Flame, 2008; 152: 604-615

9. Christos K, Björn S, Dimosthenis T, Maria F, Porous burners for low emission combustion: An experimental investigation, Energy, 2011, 45, pp. 213-219.

10. Leonardi S, Viskanta R, Gore J, Radiation and thermal performance measurements of a metal fiber burner, Journal of Quantitative Spectroscopy \& Radiative Transfer, 2002, 73, pp. 491-501

11. Michele K, Matthew J, The combustion of liquid fuels within a porous media radiant burner, Experimental Thermal and Fluid Science, 1995, 11, pp. 13-20

12. Ryo $\mathrm{T}$, Masahisa S, Norio A, Combustion characteristics of a heat-recirculating ceramic burner using a low-calorific-fuel, Energy Conversion and Management, 2001, 42, pp. 1897-1907.

13. Delalic N, Mulahasanovic D, Ganic E, Porous media compact heat exchanger unit-experiment and analysis, Experimental Thermal and Fluid Science, 2004, 28, pp. 
185-192

14. Kline SJ, McKlintock FA. Describing uncertainty in single sample experiments. Mechanical Engineering. 1953, 75, pp. 3-8

15. Turns SR. An introduction to combustion. 2nd ed. NewYork: McGraw-Hill; 2006

16. Korean Agency for Technology and Standards. KS B 8127-Condensing gas burning hot water boiler; 2010.

17. EN 677, Gas-fired central heating boilers-specific requirements for condensing boilers with a normal heat input not exceeding 70kW, 2007.

18. Byeonghun Yu, Sung-Min Kum, Chang-Eon Lee, Seungro Lee, An experimental study of heat transfer and pollutant emission characteristics at varying distances between the burner and the heat exchanger in a compact combustion system, Energy 2011, 42, pp. 350-357. 